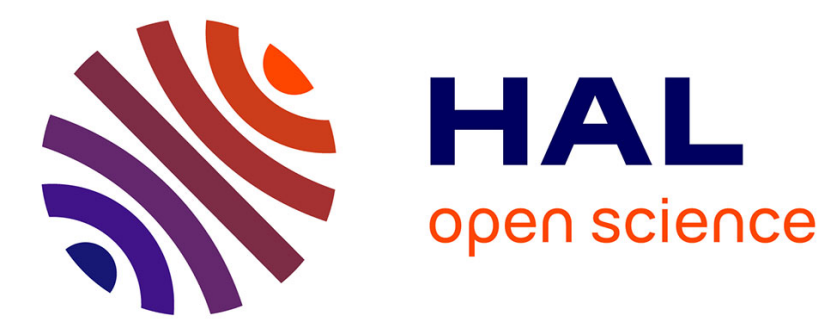

\title{
Sex-associated differences in trace metals concentrations in and on the plumage of a common urban bird species
}

\author{
Adrien Frantz, Pierre Federici, Julie Legoupi, Lisa Jacquin, Julien Gasparini
}

\section{To cite this version:}

Adrien Frantz, Pierre Federici, Julie Legoupi, Lisa Jacquin, Julien Gasparini. Sex-associated differences in trace metals concentrations in and on the plumage of a common urban bird species. Ecotoxicology, 2016, 25 (1), pp.22-29. 10.1007/s10646-015-1562-1 . hal-01332580

\section{HAL Id: hal-01332580 \\ https://hal.sorbonne-universite.fr/hal-01332580}

Submitted on 16 Jun 2016

HAL is a multi-disciplinary open access archive for the deposit and dissemination of scientific research documents, whether they are published or not. The documents may come from teaching and research institutions in France or abroad, or from public or private research centers.
L'archive ouverte pluridisciplinaire HAL, est destinée au dépôt et à la diffusion de documents scientifiques de niveau recherche, publiés ou non, émanant des établissements d'enseignement et de recherche français ou étrangers, des laboratoires publics ou privés. 
Sex-associated differences in trace metals concentrations in and on the plumage of a common urban bird species

SHORT RUNNING TITLE: Trace metals concentrations differ between sexes

FRANTZ Adrien $^{\mathrm{a}}$, FEDERICI Pierre ${ }^{\mathrm{a}}$, LEGOUPI Julie ${ }^{\mathrm{a}}, \mathrm{JACQUIN} \mathrm{Lisa}^{\mathrm{a}, \mathrm{b}}$ \& GASPARINI Julien $^{\mathrm{a}}$

${ }^{\text {a }}$ Sorbonne Universités, UPMC Univ Paris 06, UPEC, Paris 7, CNRS, INRA, IRD, Institut d'Ecologie et des Sciences de l'Environnement de Paris, F-75005, Paris, France

Corresponding author:

Adrien FRANTZ

Université Pierre et Marie Curie

Institut d'Ecologie et des Sciences de l'Environnement

7, quai St Bernard 75005 Paris, France

adrien.frantz@upmc.fr

Telephone number: +33144273823

Fax number: +33144273516 


\begin{abstract}
Urban areas encompass both favorable and stressfull conditions linked with human activities and pollution. Pollutants remain of major ecological importance for synanthropic organisms living in the city. Plumage of urban birds harbour trace metals, which can result from external deposition or from internal accumulation. External and internal plumage concentrations likely differ between specific trace metals, and may further differ between males and females because of potential sex-linked differential urban use, physiology or behaviour. Here, we measured the concentrations in four trace metals (cadmium, copper, lead and zinc) in both unwashed and washed feathers of 49 male and 38 female feral pigeons (Columba livia) from Parisian agglomeration. We found that these concentrations indeed differed between unwashed and washed feathers, between males and females, and for some metals depended on the interaction between these factors. We discuss these results in the light of physiological and behavioural differences between males and females and of spatial repartition of the four trace metals in the city.
\end{abstract}

Keywords: plumage, trace metals, urban pollution, sex-specific effects, feral pigeon 


\section{INTRODUCTION}

Urbanization is an increasingly important force modifying the landscape via habitat fragmentation and human-induced alteration of habitat structure (Antrop 2000). Despite the rapid rate of urban sprawl worldwide, conservation research has mainly focused on natural ecosystems such as old-growth forests (Fazey et al. 2005) and surprisingly little attention has been given to the study of ecological and evolutionary processes taking place in the urban environment (Miller \& Hobbs 2002; Koh \& Gardner 2010). Organisms living in cities experience various human-induced habitat modifications, including favourable conditions such as a buffering of seasonal variations in food availability and temperatures, and a relative decrease of predation risk, interspecific competition, and parasite abundance (Evans 2010; Gaston et al. 2010). However, urban conditions also induce environmental disturbances such as increased noise and exposure to chemical pollutions which may have profound consequences on local ecological processes (Gaston et al. 2010).

Human activities often generate toxic chemical compounds responsible for atmospheric pollution including trace metals (Azimi et al. 2003). Though their levels have been reduced in European countries for the last two decades, environmental concentrations in trace metals remain especially high in urban areas, due to their persistence (Hill 2004) and their numerous sources (Azimi et al. 2005b; Falq et al. 2011). A number of studies have demonstrated that these trace metals have adverse effects on physiological and ecological processes in a wide variety of taxa including annelids, fish, birds and humans (Wright \& Welbourn 2002; Hill 2004; Gasparini et al. 2014: Scheifler et al. 2006; Burger \& Gochfeld 2000; Janssens et al. 2002; Hollamby et al. 2004; Fritsch et al. 2012; Frantz et al. 2012; Espin et al. 2014, 2015).

Many studies aim at estimating metal concentrations in various body parts, either for monitoring purposes (e.g. non-invasive sampling in live animals: tegument, hair, plumage) or to evaluate short-term or long-term exposure (e.g. minimally-invasive sampling: blood; 
sampling in dead specimens: liver, bones). When considering the quantitative importance of metals in hair or plumage, special attention has to be given to the distinction between external (i.e. deposited on the external surface of plumage or hair) and internal (i.e. fixed in the internal structure of plumage or hair) metal concentrations. In birds, external metal concentrations result from deposition from the environment and from excretion of the uropygial gland during preening (Dauwe et al. 2003) adsorbed on plumage. Internal concentrations (sometimes called "constitutive"; Scheifler et al. 2006), represent metals absorbed by birds especially through respiration and feeding and internally deposited via blood in growing feathers (Burger 1993); such concentrations are positively correlated with metal levels found in other tissues such as liver and muscles (Dauwe et al. 2002). External and internal levels can strongly depend on molting status (Dauwe et al. 2003). Accordingly, metals can be measured in the feathers using two different methods: in unwashed feathers, where global concentrations include both internal and external metals; and in washed feathers, where concentrations represent internal metals, because most of (if not all) the metals externally deposited on the feathers have been removed (e.g. Burger 1993; Dauwe et al. 2003; Martínez-López et al. 2004, 2005; Scheifler et al. 2006).

The importance of external metal deposition on the feathers is likely influenced by behaviour and habitat use, which can vary between individuals and /or sexes in some species. Moreover, this inter-individual difference can further depend on the metal considered, because the relative importance of atmospheric vs. soil metals differ between metals, and because the spatial heterogeneity of atmospheric concentrations is likely much lower than the one of soil and dust concentrations. For instance, nowadays atmospheric $\mathrm{Pb}$ concentrations in Paris are nearly 0 and the external contamination on the feathers probably results from $\mathrm{Pb}$ contaminated soil particles and dusts that adsorb on plumage when bird forage on the ground (Scheifler et al. 2006), which is likely influenced by individual habitat use. On the opposite, 
atmospheric concentrations of other metals (such as $\mathrm{Zn}$ ) are likely high enough to generate high levels of external deposition and to shade slight individual differences in habitat use.

The importance of internal metal deposition in the feathers may vary between males and females because of potential sex-specific habitat use influencing the level of pollution experienced, and on sex-associated physiological processes and biochemical pathways (Burger 2007; Burger et al. 2007; Robinson et al. 2012). Furthermore, this sex-associated difference in internal deposition may depend on the metal considered, because some metals are homeostatically regulated while others are not.

In the present study, we aimed at estimating the concentrations of external and internal trace metals on the plumage of urban feral pigeons Columba livia, and test for sex-specific differences. Gender effects have received relatively little attention, often ignored probably because gender identification can be difficult, or viewed as a confounder rather than of primary importance (Burger 2007; Burger et al. 2007). In addition, measuring contaminants in unwashed and washed feathers, though important to estimate external deposition, is not a routine procedure (but see Scheifler et al. 2006; Brait \& Antoniosi Filho 2011). We have previously shown that parisian pigeons exhibit high levels of trace metals in their feathers (Frantz et al. 2012). Here, we measured trace metals concentrations in both unwashed and washed feathers of feral pigeons (Columba livia) near Paris and tested for differences in metal concentrations between males and females, which could result from sex-specific traits such as metabolisms, detoxification pathways, abilities to avoid polluted areas or grooming behaviours. Specifically, we predicted that females may harbour lower internal metal concentrations in their feathers due to metal elimination through egg-laying (Burger \& Gochfeld 1993), and that males may exhibit lower external metal concentrations on their feathers due to increased plumage cleaning behaviour linked with mate choice and sexual selection which could also increase their internal levels through preening. 


\section{MATERIALS AND METHODS}

\section{Pigeon feathers sampling}

Feathers were sampled from 87 adult pigeons caught in February 2009 in two urbanised sites located near Paris (Gennevilliers and Courbevoie). Molting influences concentrations of metals (Dauwe et al. 2003) and of other contaminants (Espín et al. 2015) in the feathers; interestingly however, molting is spread over six or more months in feral pigeons (Johnston \& Janiga 1995) and the period of most intense regrowth of feathers is usually from the end of August to mid-October (Johnston \& Janiga 1995). Consequently, feral pigeons do not differ in their molting status in February and we did not observe any inter-individual difference among our sample. To standardize the methods we collected the same feathers among individuals, namely the 3 innermost greater secondary coverts on each wing, which were sampled and stored in metal-free polyethylene bags.

Among the 6 feathers collected from each bird, 3 were randomly assigned to washing treatment while the other 3 feathers were left unwashed. The 3 former feathers were placed in Falcon tubes and washed vigorously with $0.25 \mathrm{M}$ sodium hydroxide solution $(\mathrm{NaOH}$; Scheifler et al. 2006) using a vortex mixer, rinsed energetically 3 times in distilled water to remove the external contamination using a vortex mixer, left 1 hour in distilled water, then left to dry on tissue paper during 48 hours. The other 3 feathers of each bird were not submitted to such washing treatment.

\section{Sex determination}

Feral pigeons do not exhibit a clear sexual dimorphism that could be reliably used to determine their sex. We thus determined the sex of all pigeons through genetic analyses. 
Sampling of $1 \mathrm{~mL}$ blood was realised using a 26-g needle and a syringe in the brachial vein of either right or left wing. Total blood volume collected from any individual did not exceed 2 $\mathrm{mL}$ (i.e. less than $1 \%$ of body mass as recommended by McGuill \& Rowan 1989). After sampling, blood was conserved at $4{ }^{\circ} \mathrm{C}$ until molecular sexual characterization. Briefly, $40 \mu \mathrm{L}$ of blood were collected in a PBS/EDTA anticoagulant solution. DNA was extracted using a Qiagen kit (Qiagen Sciences, DNeasy Blood and Tissue kit, cat. 69506) and amplified by polymerase chain reaction using the P8 and P2 primers following Griffiths et al. (1998).

Sexual characterisation through genetic analyses identified 38 females and 49 males among the 87 individuals caught.

\section{Trace metal measurements}

Concentrations of cadmium, copper, lead and zinc were measured in unwashed and washed feathers following the method described in Frantz et al. 2012. Briefly, feathers were dried in an oven $\left(80^{\circ} \mathrm{C}\right)$ to dry mass, crushed to powder and weighed to the nearest $0.1 \mathrm{mg}$. Feathers were then digested twice in Teflon tubes, each digestion realised in $1 \mathrm{~mL}$ nitric acid $(68 \%)$ heated to $120^{\circ} \mathrm{C}$ during 24 hours. After this double digestion in acid, $1 \mathrm{~mL}$ hydrogen peroxide (30\%) was added for 24 hours. Final volume was measured to calculate concentrations accordingly. All reagents used were AnalaR NORMAPUR ${ }^{\circledR}$ quality from VWR International S.A.S. (Radnor, Pennsylvanie, USA).

Based on the values obtained in previous studies (e.g. Adout et al. 2007; Frantz et al. 2012), we measured Zinc concentrations with flame atomic absorption spectrometry (FAAS, Unicam AA Series Spectrometer, Thermo Electron Corporation), and Copper, Cadmium and Lead concentrations using electrothermal atomic absorption spectrometry (ETAAS, Unicam 989 QZ AA Spectrometer, Zeeman SOLAAR) since these latter metals are usually in lower concentrations. Standard reference material (TM26-3, Certified Reference Material of the 
National Water Research Institute Canada) was used to validate analytical methods. Use of water instead of organic reference for analytical validation provided us with a relative, rather than an absolute, measurement of trace metals in pigeon feathers; this method appeared successful in previous studies (e.g. Gasparini et al. 2014) and suitable to our focus on potential differences between sexes. For each sample, 3 measurements of each metal were carried out and their values were averaged to get a reliable measurement of the metal concentration when the relative standard deviation (RSD) was less than 5\%. Concentrations measured were above detection limits. The detection limits were $2 \mu \mathrm{g} / \mathrm{L}(\mathrm{Pb}), 0.1 \mu \mathrm{g} / \mathrm{L}(\mathrm{Cd}), 1$ $\mu \mathrm{g} / \mathrm{L}(\mathrm{Cu})$, and $20 \mu \mathrm{g} / \mathrm{L}(\mathrm{Zn})$ respectively, while repeatability were $99.79 \%, 99.95 \%, 99.92 \%$ and 99.80\% (all $\mathrm{P}<0.0001$; Lessells \& Boag 1987).

Measurements of metals in samples of unwashed feathers were considered as including both internal and external metal concentrations, while measurements in samples of washed feathers contained internal concentrations only. Trace metals concentrations in the feathers are generally considered to adequately reflect concentrations in several tissues.

\section{Statistical analyses}

We tested for the effect of washing treatment, sex and treatment*sex interaction on the concentrations of zinc, cadmium, copper and lead (log-transformed, +1 to avoid negative logvalues when non-transformed values were less than 1) using mixed models with individual pigeon nested within location as random effect. All statistical analyses were performed using $\mathrm{R}$ (2.15.0) with package nlme. Whenever the treatment*sex interaction was significant, we performed additional analyses in separate models: first, we tested for the effect of treatment on metal concentrations in males on one hand and in females on the other hand, using two separate mixed models with treatment as fixed effect and pigeon nested in location as random effect in subsets of data containing only males or only females, respectively; then, we tested 
for the effect of sex in unwashed feathers on one hand and in washed feathers on the other hand, using two separate mixed models with sex as fixed effect and location as random effect, in subsets of data containing only washed feathers or only unwashed feathers, respectively.

\section{RESULTS}

Concentrations measured in unwashed and washed feathers of male and female feral pigeons are given in Table 1.

There was no significant effect of treatment*sex interaction on feather zinc concentrations (Table 2). The effect of treatment on zinc concentrations remained significant after removal of non-significant terms $\left(\mathrm{F}_{1,86}=7.63, \mathrm{P}=0.007\right)$ : whether males or females, feral pigeons had higher concentrations of zinc in unwashed feathers than in washed feathers (Fig. $1)$.

The effect of treatment*sex interaction on feather metal concentrations was significant for cadmium and copper, and marginally significant for lead (Table 2). In females, washing treatment had a significant, negative effect on metal concentrations (Table 3a): levels of cadmium, copper and lead were higher in unwashed feathers compared to washed feathers (Fig. 1). In constrast, treatment had no significant effect on any metal concentration in males (Table 3b), which thus had similar concentrations of these three metals in unwashed and washed feathers for these 3 metals (Fig. 1).

As compared to males, females had significantly lower concentrations of copper in washed feathers (Table 4b; Fig. 1) but not in unwashed feathers (Table 4a; Fig. 1), higher concentrations of lead in unwashed feathers (Table 4a; Fig. 1) but not in washed feathers (Table 4b; Fig. 1), and marginally significantly lower concentrations of cadmium in washed (Table 4b; Fig. 1) feathers but not in unwashed feathers (Table 4a; Fig. 1). 


\section{DISCUSSION}

We detected the presence of the 4 trace metals investigated (cadmium, copper, lead and zinc) in unwashed and washed feathers of male and female feral pigeons sampled in the Parisian region. In comparison to previous work, cadmium was in the lower range while lead, copper and zinc were in the upper ranges of concentrations measured in pigeons from other sites of the same region (Frantz et al. 2012), and all metals were from slightly higher to several dozens times more elevated than in pigeons or in other species from other regions worldwide (e.g. Janiga et al. 1990; Dauwe et al. 2003; Martínez-López et al. 2004, 2005; Nam et al. 2004; Scheifler et al. 2006; Adout et al. 2007; Brait \& Antoniosi Filho 2011; Burger et al. 2015).

We used concentrations in cadmium, copper, lead and zinc in unwashed and washed feathers to investigate possible differences in metal levels between sexes. First, we found a sex-specific effect of feather washing treatment on metal concentrations, with a higher effect of treatment in females than in males. Second, we found that this effect differed according to metals. Third, we found that internal or external concentrations differed between sexes, at least for some metals. Though measuring trace metals in feathers of several avian species, including feral pigeons (e.g. Nam \& Lee 2006), has been extensively realised, this is to our knowledge the first study to explicitely analyse the effects of washing treatment, of sex, and of their statistical interaction on metal concentrations.

Washing treatment aimed at eliminating metal external deposition. Thus, sex-linked differences in the effect of washing treatment on metal concentrations likely reflect different external depositions of metals on the feathers between males and females: females exhibit metals on their feathers, while the external surface of the male plumage appears to be virtually free of three of the metals analysed. These sex-linked differences may result from various 
causes. First, sex-specific exposure to pollutants could result from sex differences in spatiotemporal use of urban areas: in Basel (Switzerland), male feral pigeons spent less time outside the loft and flew shorter distances than females (maybe due to sex-specific constraints, such as territory defence in males vs. food search in females; Rose et al. 2006), potentially resulting in lower metal exposure among males. However, urban foraging behaviour among feral pigeons in Paris remains unknown; importantly, both sexes were caught at the very same sites in the present and previous studies (Frantz et al. 2012; Jacquin et al. 2012). External contamination onto the feather surface may also originate from secretion products of the uropygial gland smeared during preening (Burger 1993; Pilastro et al. 1993). However, this gland in pigeons is very small and some individuals even lack it (Darwin 1868; Johnston 1988; Moyer et al. 2003), hence its influence on external metal levels is likely low in this species. Consequently, sex-linked differences in the importance of external deposition of metals more likely result from differences in plumage care.

Indeed, higher allocation into plumage grooming in males would result in very low metals levels at the surface of their feathers, as compared to females. Feral pigeons care of their plumage through grooming behaviour, which includes preening, foot scratching, down powder dispersal, bathing and sunning (Johnston \& Janiga 1995). Accordingly, behavioural observations in captivity show a higher amount of time devoted to grooming behaviours in male pigeons compared to females (Jacquin L. unpublished). This possible sex-specific behaviour in plumage cleaning would be in line with sexual selection. Pair bonding in feral pigeons results from choice by females based on several criteria such as courtship display and plumage coloration (Murton et al. 1973; Johnston \& Johnson 1989). The importance of male plumage care in mate choice have been experimentally demonstrated in feral pigeons (Clayton 1990): females prefer parasite-free males, potentially by detecting altered courtship display caused by ectoparasites. Grooming could then also efficiently eliminate metals, 
among other particles, from the surface of the plumage, and explain our observations. Urban pollution could also alter plumage quality by altering visual characteristics (such as in reflectance in UV range and yellow chroma Griggio et al. 2011; Pérez-Rodríguez et al. 2011; Surmacki 2011) and select for increased plumage care among males.

Interestingly, we found differences between metals: contrary to what we found for the three other metals, external depositions in zinc were similar between males and females. This particular case of zinc can be linked with overall importance in urban areas, and with the fact that zinc is an essential element. The overall prevalence of zinc in urban environments partially results from its widespread use (for instance for roof covering; Gromaire-Mertz et al. 1999), inducing high amounts of zinc in roof run-off waters during rain events (80 times higher than atmospheric deposition; Rocher et al. 2004). In addition, zinc atmospheric concentrations remain very high in urban areas. High concentrations of zinc in urban areas, especially in the atmosphere, might thus shade differences in external depositions on the plumage between sexes: cleaning feathers from zinc would not be efficient enough to significantly decrease deposition of this ubiquitous metal. On the opposite, atmospheric concentrations of some metals are very low (e.g. copper, lead, cadmium; Azimi et al. 2005a) and metal-contaminated particles and dusts have the highest contribution in external deposition; as a result, higher investment in grooming behaviour among males would explain the difference in external levels of these metals observed between sexes. In addition, zinc is an essential element that is required for normal feather formation (Sunde 1972), and it has been previously suggested that exogenous contamination may be a less important factor of zinc contamination in feathers (Jaspers et al. 2004). Thus, deposition rate of zinc into the feathers is high and may mask exogenous contamination.

In addition, we found lower internal levels of cadmium and copper within feathers in females compared to males. Sex-differences in metal concentrations in the feathers have been 
observed previously, though not consistently throughout studies. When evidenced, sexspecific differences in metal concentrations in the feathers are usually attributed to various mechanisms (e.g. sex-linked differences in excretion opportunities, in trophic levels, in size dimorphism conferring access to different sizes of prey (Bearhop et al. 2006) with varying metal content; see Ramos et al. 2009). In pigeons, males and females did not differ in lead, cadmium and iron in their feathers (Janiga et al. 1990). Altogether, literature investigating sex-differences for metal exposure in birds is scarce and somehow leads to inconsistent results, and a clear pattern has not yet been established (Burger 2007), probably because the levels of metals in the feathers depend on many factors. The differences in metal concentrations within feathers observed here between males and females could thus result from various mechanisms (e.g. sex-specific foraging behaviours influencing exposure, differences in metabolic or detoxification pathways); interestingly, higher investment in grooming behaviour in males could also explain the differences in internal contents of their feathers: preening with the bill is probably the most important grooming activitiy (e.g. Clayton 1991), during which birds handle a great nuber of their feathers every day with their bills, nibbling and stroking each feather with the bill tips (Johnston \& Janiga 1995). This behaviour may efficiently remove some of the external metal contamination which could then be transferred via the bill to the digestive track and increase the internal level. In addition, based on several studies showing significantly metal concentrations in eggs presumably originating from female body (Bryan et al. 2003; Burger et al. 2004; Burger et al. 2009; Metcheva et al. 2011), we predicted lower metal concentations within feathers in females resulting from metals elimination through egg deposition. Our results were consistent with this prediction for copper and (marginally) cadmium concentrations, while the concentrations of zinc and lead in washed feathers did not significantly differ between sexes. Alternative 
mechanisms can not be ruled out and further studies are required to shed light on these sexassociated processes.

To conclude, sex-specific differences in internal and external trace metals showed here could result from different behaviours between males and females, such as increased grooming and cleaning behaviour among males, possibly linked with sexual selection. Female choice could act as a selective pressure favouring male ability to enhance plumage care, which would in turn increase internal levels of metals (and potentially other particles, dust, pollutants) in polluted areas. Future work should directly investigate the potential effect of external pollutants on plumage visual characteristics which could potentially modulate the expression of sexual ornaments and mate choice in polluted areas.

We believe that trace metals concentrations can be useful in investigating evolutionary and ecology processes, including dispersal (Frantz et al. 2012), natural selection and sexual selection. Such studies require not only to control for gender as a factor potentially influencing metal exposure, but to specifically focus on potential gender-differences (Burger 2007) in future work investigating evolutionary ecotoxicological concepts. 


\section{ACKNOWLEDGEMENTS}

We thank two anonymous referees for their useful comments on the original version of the manuscript. We thank Emmanuel Aubry, Maryse Castrec-Rouelle, Marie-Anne Pottier, Lorenzo Ricci, Battle Karimi and Audrey Foubert for their help in trace metal measurements, as well as Ahmed Belguermi and Philippe Lenouvel for help in feather sampling. We are grateful to Anne-Caroline Prévot-Julliard, to the scientific network "Le pigeon en ville", to the AERHO association, to the ESPACES association and to the "Mairie de Paris" (Thomas Charachon) for providing logistic support during the field work. All experiments were conducted under the authorization of the "Direction Départementale des Services Vétérinaires de Seine-et-Marne" (authorization No 77-07).

\section{Funding}

Funding was provided by the Université Pierre et Marie Curie (FR) and the Centre National de la Recherche Scientifique (FR). None of my funders had any influence on the content of the submitted or published manuscript. None of my funders require approval of the final manuscript to be published.

The authors declare that they have no conflict of interest. 


\section{LITERATURE CITED}

1. Adout A., Hawlena D., Maman R., Paz-Tal O. \& Karpas Z. (2007). Determination of trace elements in pigeon and raven feathers by ICPMS. International Journal of Mass Spectrometry, $267: 109-116$.

2. Antrop, M. (2000). Changing patterns in the urbanized countryside of Western Europe. Landscape Ecol., 15 : 257-270.

3. Azimi S., Ludwig A., Thévenot D.R. \& Colin J.L. (2003). Trace metal determination in total atmospheric deposition in rural and urban areas. The Science of the Total Environment, $308: 247-256$.

4. Azimi, S., Rocher, R., Garnaud, S., Varrault, G., Thévenot, D.R., 2005a. Decrease of atmospheric deposition of heavy metals in an urban area from 1994 to 2002 (Paris, France). Chemosphere 61, 645-651.

5. Azimi S., Rocher R., Muller M., Moilleron R. \& Thévenot D.R. (2005b). Sources, distribution and variability of hydrocarbons and metals in atmospheric deposition in an urban area (Paris, France). Sci. Total Environ. 337 : 223-239.

6. Brait C.H.H. \& Antoniosi Filho N.R. (2011). Use of feathers of feral pigeons (Columba livia) as a technique for metal quantification and environmental monitoring. Environmental Monitoring and Assessment, 179: 457-467.

7. Braune BM (1987) Mercury accumulation in relation to size and age of Atlantic herring (Clupea harengus harengus) from the southwestern Bay of Fundy, Canada. Arch Environ Contam Toxicol, 16: 311-320.

8. Bryan A.L. Jr., Hopkins W.A., Baionno J.A. \& Jackson B.P. (2003). Maternal transfer of contaminants to eggs in common grackles (Quiscalus quiscala) nesting on coal fly ash basins. Arch. Environ. Contam. Toxicol. 45, 273-277. 
9. Burger J. (1993). Metals in avian feathers: bioindicators of environmental pollution. Rev. Environ. Toxicol., 5: 203-311.

10. Burger J. (2007). A framework and methods for incorporating gender-related issues in wildlife risk assessment: gender-related differences in metal levels and other contaminants as a case study. Environmental Research, 104: 153-162.

11. Burger J., Bowman R., Woolfenden G.E. \& Gochfeld M. (2004). Metal and metalloid concentrations in the eggs of threatened Florida scrub-jays in suburban habitat from south-central Florida. Science of the Total Environment 328, 185-193.

12. Burger J., Fossi C., McClellan-Green P., Orlando E.F. (2007). Methodologies, bioindicators, and biomarkers for assessing gender-related differences in wildlife exposed to environmental chemicals. Environmental Research, 104: 135-152.

13. Burger J. \& Gochfeld M. (1993). Heavy metal and selenium levels in feathers of young egrets and herons from Hong Kong and Szechuan, China. Arch. Environ. Contam. Toxicol., 25: 322-327.Burger J. \& Gochfeld M. (2000). Metal levels in feathers of 12 species of seabirds from Midway Atoll in the northern Pacific Ocean. The Science of the Total Environment, 257: 37-52.

14. Burger J., Gochfeld M., Jeitner C., Burke S., Volz C.D., Snigaroff R., Snigaroff D., Shukla T. \& Shukla S. (2009). Mercury and other metals in eggs and feathers of glaucous-winged gulls (Larus glaucescens) in the Aleutians. Science of the Total Environment 328, 185-193.

15. Burger J., Tsipoura N., Niles L.J., Gochfeld M., Dey A. \& Mizrahi D. (2015). Mercury, lead, cadmium, arsenic, chromium and selenium in feathers of shorebirds during migrating through Delaware Bay, New Jersey: comparing the 1990s and 2011/2012. Toxics, 3: 63-74. 
16. Clayton D.H. (1990). Mate choice in experimentally parasitized rock doves: lousy males lose. Amer. Zool., $30: 251-262$.

17. Clayton D.H. (1991).Coevolution of avian grooming and ectoparasite avoidance. In Bird-parasite interactions (eds. E. Loye \& M. Zuk), pp. 258-289. Oxford University Press, Oxford.

18. Darwin C. (1868). Darwin, C. R. 1868. The variation of animals and plants under domestication. John Murray, London.

19. Dauwe T., Bervoets L., Blust R. \& Eens M. (2002). Tissue levels of lead in experimentally exposed zebra finches (Taeniopygia guttata) with particular attention on the use of feathers as biomonitors. Arch. Environ. Contam. Toxicol., 42 : 88-92.

20. Dauwe T., Bervoets L,. Pinxten R., Blust R. \& Eens M. (2003). Variation of heavy metals within and among feathers of birds of prey: effects of molt and external contamination. Environ. Pollut., 124: 429-36.

21. Espín S., Martínez-López E., León-Ortega M., Martínez J.E. \& García-Fernández A.J. (2014). Oxidative stress biomarkers in Eurasian eagle owls (Bubo bubo) in three different scenarios of heavy metal exposure. Environmental Research, 131: 134-144.

22. Espín S., Martínez-López E., Jiménez P., María-Mojica P \& García-Fernández A.J. (2015). Delta-aminolevulinic acid dehydratase ( $\delta$ ALAD) activity in four free-living bird species exposed to different levels of lead under natural conditions. Environmental Research, 137: 185-198.

23. Evans K.L. (2010). Individual species and urbanisation. In Urban ecology (Gaston K.J. ed), pp. 53-87, Cambridge University Press.

24. Falq G., Zeghnoun A., Pascal M., Vernay M., Le Strat Y., Garnier R., Olichon D., Bretin P., Castetbon K. \& Fréry N. (2011). Blood lead levels in the adult population 
living in France the French Nutrition and Health Survey (ENNS 2006-2007). Environment International, 37: 565-571.

25. Fazey I., Fischer J., \& Lindenmayer D. B. (2005). What do conservation biologists publish? Biol. Conserv. 124 : 63-73. (DOI 10.1016/j.biocon.2005.01.013)

26. Frantz A., Pottier M.A., Karimi B., Corbel H., Aubry E., Haussy C., Gasparini J. \& Castrec-Rouelle M. (2012). Contrasting levels of trace metals in the feathers of urban pigeons from close habitats suggest limited movements at a restricted scale. Environ. Pollut., 168: 23-28.

27. Fritsch C., Coeurdassier M., Faivre B., Baurand P.E., Giraudoux P., van den Brink N.W. \& Scheifler R. (2012). Influence of landscape composition and diversity on contaminant flux in terrestrial food webs: a case study of trace metal transfer to European blackbirds Turdus merula. Science of The Total Environment, 432: 275287.

28. Gasparini J., Jacquin L., Laroucau K., Vorimore F., Aubry E., Castrec-Rouelle M., \& Frantz A. (2014). Relationships between metals exposure and epidemiological parameters of two pathogens in urban pigeons. Bulletin of Environmental Contamination and Toxicology, 92: 208-212.

29. Gaston K.J., Davies Z.G. \& Edmondson J.L. (2010). Urban environments and ecosystem functions. In Urban ecology (Gaston K.J. ed), pp. 35-52, Cambridge University Press.

30. Griffiths R., Double M.C., Orr K. \& Dawson RJ.G. (1998). A DNA test to sex most birds. Molecular Ecology, 7: 1071-1075.

31. Griggio M., Serra L. \& Pilastro A. (2011). The possible effect of dirtiness on structurally based ultraviolet plumage. Italian journal of zoology, 78: 90-95. 
32. Gromaire-Mertz M.C., Garnaud S., Gonzalez A. \& Chebbo G. (1999).

Characterisation of urban runoff pollution in Paris. Wat. Sci. Tech., 39: 1-8.

33. Hill M.K. (2004). Metals. In Understanding Pollution (eds. Wright D.A. \& Welbourn P.), pp. 350-371. Cambridge University Press, Cambridge.

34. Hollamby S., Afema-Azikuru J., Sikarskie J.G., Kaneene J.B., Bowerman W.W., Fitzgerald S.D., Cameron K., Gandolf A.R., Hui G.N., Dranzoa C. \& Rumbeiha W.K. (2004). Mercury and persistent organic pollutant concentrations in african fish eagles, marabou sotriks, and nile tilapia in Uganda. Journal of Wildlife Diseases, 40 : 501514.

35. Janiga M., Maňkovská B., Bobal'ová M. \& Ďurkčová G. (1990). Significance of concentrations of lead, cadmium, and iron in the plumage of the feral Pigeon. Archives of Environmental Contamination and Toxicology, 19: 892-897.

36. Janssens E., Dauwe T., Bervoets L. \& Eens M. (2002). Inter- and intraclutch variability in trace metals in feathers of Great Tit nestlings (Parus major) along a pollution gradient. Archives of Environmental Contamination and Toxicology, 43: 323-329.

37. Jaspers V., Dauwe T., Pinxten R., Bervoets L., Blust R. \& Eens M. (2004). The importance of exogenous contamination on heavy metal levels in bird feathers. A field experiment with free-living great tits, Parus major. Journal of Environmental Monitoring, 6: 356-360.

38. Johnston D.W. (1988.) A morphological atlas of the avian uropygial gland. Bulletin of the British Museum of Natural History, 54: 1-259.

39. Johnston R.F \& Janiga M. (1995). Feather maintenance and the molt. In Feral pigeons, p.167-173. Oxford University Press, Oxford. 
40. Johnston R.F. \& Johnson S. (1989). Non random mating in feral pigeons. The Condor, $91: 23-29$.

41. Koh L.P. \& Gardner, T. A. (2010). Conservation in human modified landscapes. In Conservation biology (eds N.S. Sodhi \& P.E. Ehrlich), pp. 236-261. Oxford University Press.

42. Lessells C.M. \& Boag P.T. (1987). Unrepeatable repeatabilities: a common mistake. The Auk, 104: 116-121.

43. Martínez-López E., María-Mojica P., Martínez J.E., Calvo J.F., Romero D. \& GarcíaFernández, A.J. (2005). Cadmium in feathers of adults and blood of nestlings of three raptor species from a nonpolluted mediterranean forest, southeastern Spain. Bull. Environ. Contam. Toxicol., 74: 477-484.

44. Martínez-López E., Martínez J.E., María-Mojica P., Peñalver J., Pulido M., Calvo J.F. \& García-Fernández, A.J. (2004). Lead in feathers and $\delta$-aminolevulinic acid dehydratase activity in three raptor species from an unpolluted mediterranean forest (Southeastern Spain). Archives of Environmental Contamination and Toxicology, 47: $270-275$.

45. McGuill M.W. \& Rowan A.N. (1989). Biological effects of blood loss: implications for sampling volumes and techniques. ILAR News, 31: 5-18.

46. Metcheva R., Yurukova L. \& Teodorova S.E. (2011). Biogenic and toxic elements in feathers, eggs, and excreta of Gentoo penguin (Pygoscelis papua ellsworthii) in the Antarctic. Environ Monit Assess, 182: 571-585.

47. Miller J.R. \& Hobbs R.J. (2002). Conservation where people live and work. Conserv. Biol. 16 : 330-337. (DOI 10.1046/j.1523-1739.2002.00420.x)

48. Moyer B.R., Rock A.N. \& Clayton D.H. (2003). Experimental test of the importance of preen oil in Rock doves (Columba livia). The Auk, 120: 490-496. 
49. Murton R.K., Westwood N.J. \& Thearle R.J.P. (1973). Polymorphism and the evolution of a continuous breeding season in the pigeon, Columba livia. J. Reprod. Fert. Suple., 19: 63-577.

50. Nam, D.H. \& Lee D.P (2006). Monitoring for Pb and Cd pollution using feral pigeons in rural, urban, and industrial environments of Korea. Science of the Total Environment, 357: 288-295.

51. Nam, D.H., Lee D.P. \& Koo T.H. (2004). Monitoring for lead pollution using feathers of feral Pigeons (Columba livia) from Korea. Environmental Monitoring and Assessment, 95: 13-22.

52. Pérez-Rodríguez L. \& Mougeot F. \& Bortolotti G.R. (2011). The effects of preen oils and soiling on the UV-visible reflectance of carotenoid-pigmented feathers. Behav Ecol Sociobiol, 65:1425-1435.

53. Pilastro A., Congiu L., Tallandini L. \& Turchetto M. (1993). The use of bird feathers for the monitoring of cadmium pollution. Arch. Environ. Cont. Tox. 24: 355-358.

54. Robinson S.A., Lajeunesse M.J. \& Forbes M.R. (2012). Sex differences in mercury contamination of birds: testing multiple hypotheses with meta-analysis. Environmental Science \& Technology, 46: 7084-7101.

55. Rocher V., Azimi S., Gaspéri J., Beuvin L., Muller M., Moilleron R. \& Chebbo G. (2004). Hydrocarbons and metals in atmospheric deposition and roof runoff in central Paris. Water, Air, and Soil Pollution, 159: 67-86.

56. Rose E., Nagel P. \& Haag-Wackernagel D. (2006). Spatio-temporal use of the urban habitat by feral pigeons. Behav. Ecol. Sociobiol., 60: 242-254.

57. Scheifler R., Coeurdassier M., Morilhat C., Bernard N., Faivre B., Flicoteaux P., Giraudoux P., Noël M., Piotte P., Rieffel D., de Vaufleury A. \& Badot P.M. (2006). Lead concentrations in feathers and blood of common blackbirds (Turdus merula) and 
in earthworms inhabiting unpolluted and moderately polluted urban areas. Science of the Total Environment, 371 : 197-205.

58. Sunde M.L. (1972). Zinc requirement for normal feathering of commercial leghorntype pullets. Poultry Science, 51: 1316-1322.

59. Surmacki A. (2011). Natural soiling has a small effect on structurally-based plumage coloration. Animal Biology, 61: 441-455.

60. Wright D.A. \& Welbourn P. (2002). Metals and other inorganic chemicals. In Environmental toxicology (eds. Wright D.A. \& Welbourn P.), pp. 249-348. Cambridge University Press, Cambridge. 
Table 1: Concentrations (means in $\mu \mathrm{g} . \mathrm{g}^{-1}+/-$ standard error) of zinc, cadmium, copper, and lead measured before and after washing treatment in male and female feral pigeons.

\begin{tabular}{|c|c|c|c|c|c|}
\hline & & \multicolumn{2}{|l|}{ Males } & \multicolumn{2}{|l|}{ Females } \\
\hline & & unwashed & washed & unwashed & washed \\
\hline \multirow[t]{4}{*}{ Metal } & zinc & $366+/-45$ & $325+/-30$ & $373+/-35$ & $279+/-19$ \\
\hline & cadmium & $0.52+/-0.07$ & $0.51+/-0.06$ & $0.46+/-0.06$ & $0.38+/-0.04$ \\
\hline & copper & $25.4+/-5.0$ & $36.4+/-7.8$ & $24.8+/-3.9$ & $17.1+/-1.4$ \\
\hline & lead & $23.9+/-3.0$ & $25.0+/-2.7$ & $21.6+/-2.4$ & $28.9+/-3.4$ \\
\hline
\end{tabular}


Table 2: Results of the complete models fitted for the effects of treatment, sex and their interaction on the concentrations in each metal (cadmium, copper, lead and zinc). Significant effects are shown: ${ }^{\wedge}, \mathrm{P}<0.10 ; *, \mathrm{P}<0.05 ; * *, \mathrm{P}<0.01$.

\begin{tabular}{|c|c|c|c|c|}
\hline & & \multicolumn{3}{|l|}{ Factor } \\
\hline & & treatment & sex & treatment*sex \\
\hline \multirow[t]{8}{*}{ Metal } & zinc & $\mathrm{F}_{1,85}=8.53$ & $\mathrm{~F}_{1,84}=0.04$ & $\mathrm{~F}_{1,85}=1.76$ \\
\hline & & $\mathrm{P}=0.005 * *$ & $\mathrm{P}=0.84$ & $\mathrm{P}=0.19$ \\
\hline & cadmium & $\mathrm{F}_{1,85}=2.25$ & $\mathrm{~F}_{1,84}=0.80$ & $\mathrm{~F}_{1,85}=3.81$ \\
\hline & & $\mathrm{P}=0.14$ & $\mathrm{P}=0.37$ & $\mathrm{P}=0.054^{\wedge}$ \\
\hline & copper & $\mathrm{F}_{1,85}=0.01$ & $\mathrm{~F}_{1,84}=0.81$ & $\mathrm{~F}_{1,85}=5.93$ \\
\hline & & $\mathrm{P}=0.91$ & $\mathrm{P}=0.37$ & $\mathrm{P}=0.017 *$ \\
\hline & lead & $\mathrm{F}_{1,85}=1.02$ & $\mathrm{~F}_{1,84}=1.36$ & $\mathrm{~F}_{1,85}=9.9$ \\
\hline & & $\mathrm{P}=0.32$ & $\mathrm{P}=0.25$ & $\mathrm{P}=0.002 * *$ \\
\hline
\end{tabular}


Table 3: Results of the two separate models fitted for the effect of treatment on the feather concentrations in each metal a) in males and b) in females. Significant effects are shown: ${ }^{\wedge}, \mathrm{P}<0.10 ; *, \mathrm{P}<0.05 ; * *, \mathrm{P}<0.01$.

Factor: treatment
a) in females
b) in males

\begin{tabular}{lll}
\hline Metal cadmium & $\mathrm{F}_{1,37}=6.61$ & $\mathrm{~F}_{1,48}=0.10$ \\
& $\mathrm{P}=0.014 *$ & $\mathrm{P}=0.76$ \\
\hline copper & $\mathrm{F}_{1,37}=6.53$ & $\mathrm{~F}_{1,48}=2.15$ \\
& $\mathrm{P}=0.015^{*}$ & $\mathrm{P}=0.15$ \\
\hline lead & $\mathrm{F}_{1,37}=10.11$ & $\mathrm{~F}_{1,48}=2.20$ \\
& $\mathrm{P}=0.003 * *$ & $\mathrm{P}=0.14$ \\
\hline
\end{tabular}


Table 4: Results of the two separate models fitted for the effect of sex on the concentrations in each metal in a) unwashed feathers and b) washed feathers.

Significant effects are shown: ${ }^{\wedge}, \mathrm{P}<0.10 ; *, \mathrm{P}<0.05$.

\begin{tabular}{|c|c|c|c|}
\hline & & \multicolumn{2}{|l|}{ Factor: sex } \\
\hline & & a) in unwashed feathers & b) in washed feathers \\
\hline \multirow[t]{6}{*}{ Metal } & cadmium & $\mathrm{F}_{1,84}=0.01$ & $\mathrm{~F}_{1,84}=3.23$ \\
\hline & & $\mathrm{P}=0.93$ & $\mathrm{P}=0.076^{\wedge}$ \\
\hline & copper & $\mathrm{F}_{1,84}=0.99$ & $\mathrm{~F}_{1,84}=5.33$ \\
\hline & & $\mathrm{P}=0.32$ & $\mathrm{P}=0.023 *$ \\
\hline & lead & $\mathrm{F}_{1,84}=6.04$ & $\mathrm{~F}_{1,84}=0.24$ \\
\hline & & $\mathrm{P}=0.016^{*}$ & $\mathrm{P}=0.62$ \\
\hline
\end{tabular}



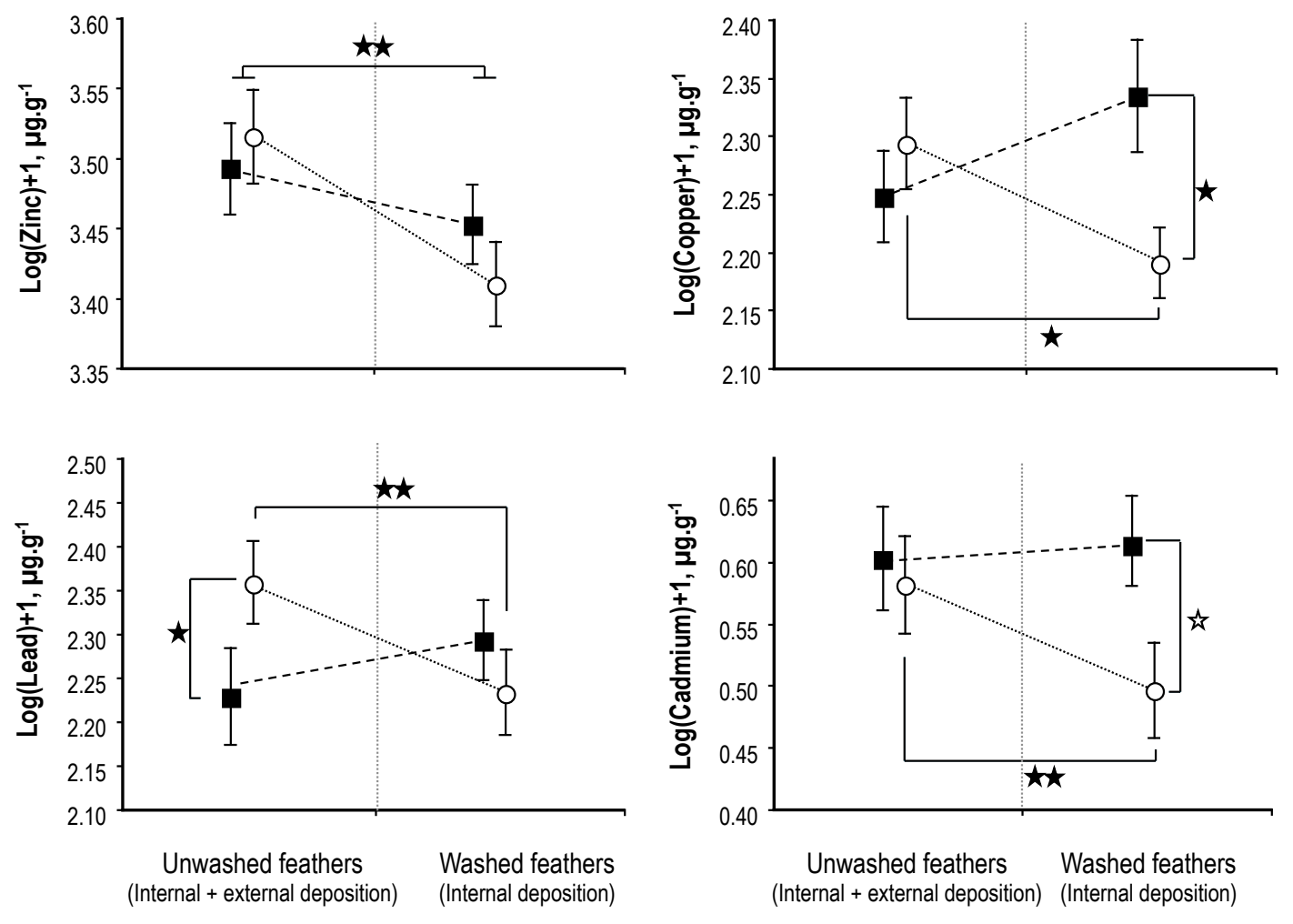

oFemales

-Males

\section{FIGURE CAPTION}

Fig. 1: Log-transformed concentrations (mean and standard error) in zinc, cadmium, copper, and lead measured in pigeon feathers according to sex and washing treatment. Only significant differences are shown (open star: $\mathrm{P}<0.10$; single filled star $\mathrm{P}<0.05$; double filled star $\mathrm{P}<0.01)$. 